Article

\title{
Increasing the Enzyme Loading Capacity of Porous Supports by a Layer-by-Layer Immobilization Strategy Using PEI as Glue
}

\author{
Nathalia S. Rios ${ }^{1,2}$, Sara Arana-Peña ${ }^{1}$, Carmen Mendez-Sanchez ${ }^{1}$, Yuliya Lokha ${ }^{1}$, \\ Vicente Cortes-Corberan ${ }^{3}\left(\mathbb{D}\right.$, Luciana R. B. Gonçalves ${ }^{2} \mathbb{D}$ and Roberto Fernandez-Lafuente $1, * \mathbb{D}$ \\ 1 Departamento de Biocatálisis. ICP-CSIC, Campus UAM-CSIC, 28049 Madrid, Spain \\ 2 Departamento de Engenharia Química, Universidade Federal do Ceará, Campus do Pici, Bloco 709, \\ Fortaleza, CE CEP 60455-760, Brazil \\ 3 Departamento de Catálisis Aplicada. ICP-CSIC, Campus UAM-CSIC, 28049 Madrid, Spain \\ * Correspondence: rfl@icp.csic.es; Tel.: +34-915-854-941
}

Received: 12 June 2019; Accepted: 29 June 2019; Published: 29 June 2019

\begin{abstract}
A new strategy to increase the enzyme-loading capacity of porous supports was investigated. Lipase from Pseudomonas fluorescens (PFL) was immobilized on octyl-agarose (OA) beads and treated with polyethyleneimine (PEI). Then, PFL was immobilized on the previous PFL layer. Next, the biocatalyst was coated with PEI and a third layer of PFL was added. Sodium dodecyl sulfate polyacrylamide electrophoresis showed that the amount of PFL proportionally increased with each enzyme layer; however, the effects on biocatalyst activity were not as clear. Hydrolyzing $50 \mathrm{mM}$ of triacetin at $25^{\circ} \mathrm{C}$, the activity of the three-layer biocatalyst was even lower than that of the bi-layer one; on the contrary its activity was higher when the activity was measured at $4{ }^{\circ} \mathrm{C}$ in the presence of $30 \%$ acetonitrile (that reduced the activity and thus the relevance of the substrate diffusion limitations). That is, the advantage of the multilayer formation depends on the specific activity of the enzyme and on the diffusion limitations of the substrate. When octyl agarose (OA)-PFL-PEI-PFL preparation was treated with glutaraldehyde, the activity was reduced, although the enzyme stability increased and the immobilization of the last PFL layer offered results similar to the one obtained using the three-layer preparation without glutaraldehyde modification (90\%).
\end{abstract}

Keywords: biocatalyst volumetric activity; enzyme immobilization multilayers of enzyme; lipase from Pseudomonas fluorescens; polyethyleneimine

\section{Introduction}

Enzyme immobilization is a key step in the enzyme biocatalyst design [1]. Initially, its purpose was just to facilitate the reuse of these expensive biocatalysts. However, soon, the technique showed a great potential to improve many enzyme properties, such as stability, selectivity, specificity, purity, etc. [2-11]. The selection of the support is in many instances decisive for the final implementation of the biocatalysts [12]. Price is considered relevant in some instances, but that depends on the degree of enzyme improvement that can be achieved after immobilization and on other features of the support [11]. Their mechanical properties should be compatible with the reactor system. For instance, porous rigid supports like silicates are useful for fixed bed reactors, but they can be broken in stirred systems, while flexible supports are adequate for stirred systems but produce problems in fixed bed reactors [1]. The particle size should be adequate for the filters and catalysts retention equipment. Moreover, one very important feature is the enzyme loading capacity: if one can immobilize twice the amount of enzyme on one support than on another, the support price of the final catalyst is reduced by half [12]. 
In a similar way, large-size non-porous supports offer a very low specific area and low loading, unless going down to nanoscale, and in this case handling and price may become problematic [1,13-16], as standard filters will be inefficient to retain the biocatalyst. The impact of enzyme loading capacity of the support on the support selection could be reduced if somehow one could increase the loading capacity of the support. This could be achieved if one enzyme layer is immobilized over a previously immobilized enzyme layer, making it possible to load enzyme until the entry of new enzyme molecules is hindered by the reduction of the support pore size, or substrate diffusional limitations make inefficient the firstly immobilized enzyme molecules layer near to the support surface. Using a non-porous support, the only relevant substrate diffusion problem will be the diffusion from the upper enzyme layer to the lower enzyme layer in contact with the support, while using porous supports, the entry of the substrate in the particle can increase the diffusion problems. The enzyme activity may play an important role on the importance of these substrate diffusion problems, a poorly effective enzyme may be a good model [17], but we can mimic this by using experimental conditions where the enzyme activity decrease.

To reach this goal, it is necessary to "activate" the immobilized enzyme molecules surface in a way that allows the immobilization of a new layer of enzymes. This may be achieved using polyethylenimine (PEI) [18-21] (Figure 1). This polymer is multicationic, has primary, secondary and tertiary amino groups and has been broadly used in biocatalysis design, in some instances to coimmobilize enzymes [22,23] or enzymes and cofactors [24-26]. The only problem (with the second and further enzyme layers) of this new strategy is that, after immobilizing the enzyme via ion exchange on PEI, the new coating with PEI of the previously ionically exchanged enzyme could produce some enzyme leaching from the support by competition among the PEI coating the previously immobilized enzyme layer, the immobilized enzyme molecules layer and the new doses of free PEI.

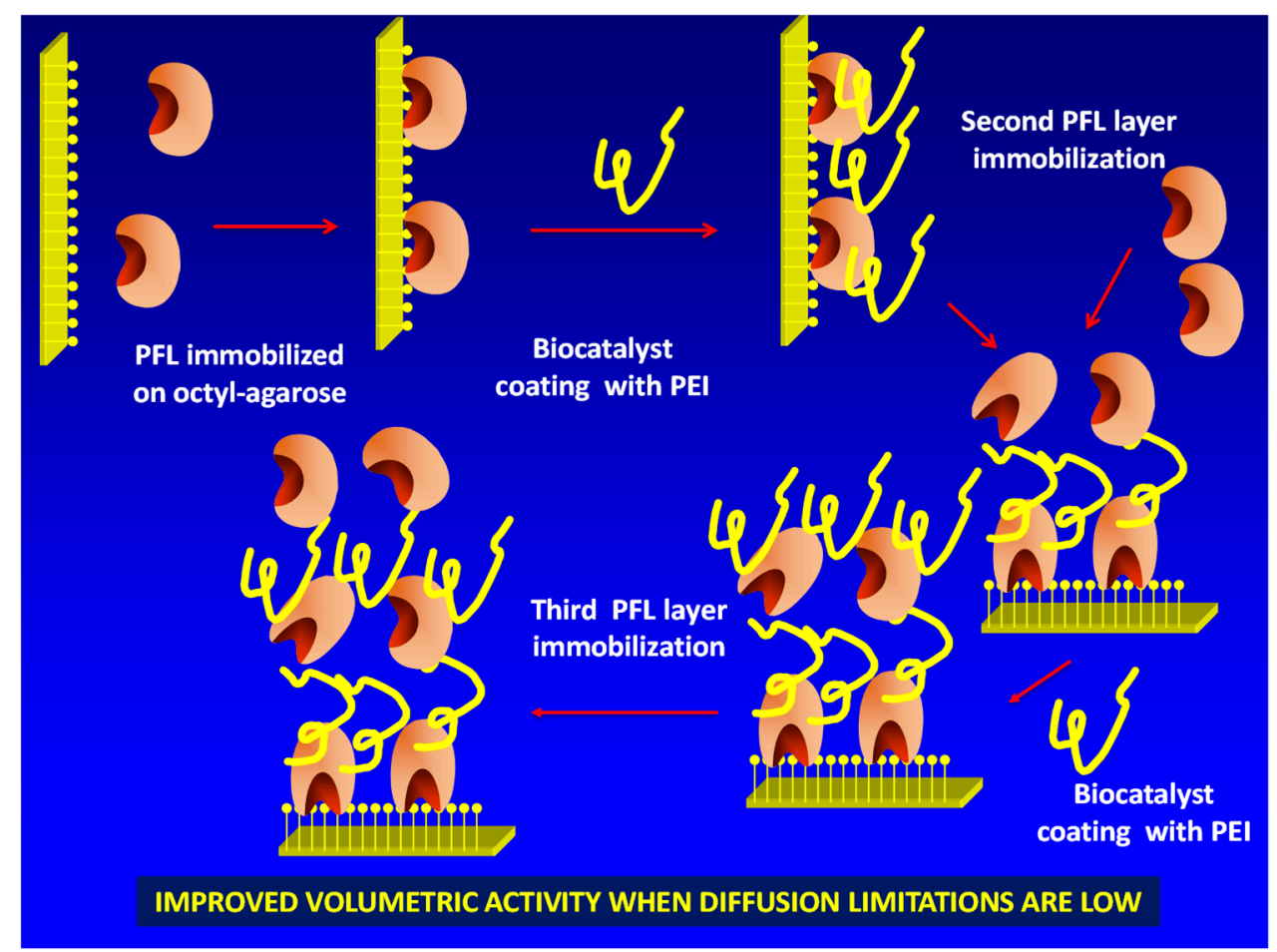

Figure 1. Scheme of the multilayer immobilization strategy proposed in this paper. PEI: polyethylenimine; PFL: lipase from Pseudomonas fluorescens.

In this first approach, we have tried to build a three-layer biocatalyst using the lipase from Pseudomonas fluorescens (PFL). This enzyme is very popular in literature [27-29]. To simplify the study, we have immobilized a first layer of PFL on octyl agarose (OA) beads via interfacial activation, a kind 
of lipase biocatalysts often submitted to the coating with PEI to prevent enzyme release under drastic conditions, thus improving the immobilized enzyme stability [30-32]. The lipase immobilization via interfacial activation on hydrophobic supports mimics the adsorption of lipases on substrate drops and involves the hydrophobic areas of the enzyme near to the active center. The adsorption is strong but the large size of the enzyme pocket and the layer of octyl groups leaves a space large enough to the substrates to reach the active center of the enzyme, even giving usually a lipase hyperactivation due to the involvement of the open form of the lipase in the immobilization [33,34].

Next, the immobilized enzyme was coated with PEI. Then, we immobilized a second layer of PFL on the PEI layer and studied if a new coating with PEI could produce the release of the ionically exchanged enzymes. If this leaching did not occur, a third layer of enzyme was immobilized. The effect of this layer-by-layer biocatalyst building on the biocatalysts volumetric activity was evaluated using different substrates and conditions. It may be expected that when specific activity of the enzyme is very high, the volumetric activity of the biocatalysts may not be increased by using this multilayer strategy due to the increase of substrate diffusional limitations (diffusion of substrate rate may be lower than enzyme substrate consumption rate) [35-38]. However, if the specific enzyme activity is not very high and substrate diffusion limitations are scarce, a continuous increase in enzyme activity may be expected when the number of enzyme layers increases.

\section{Results and Discussion}

\subsection{Immobilization of PFL on octyl agarose}

To take full advantage of this strategy, maximum PFL loading of octyl agarose must be utilized. Thus, Figure 2 shows the immobilization yields at different PFL loadings: $1 \mathrm{mg} / \mathrm{g}$ and $80 \mathrm{mg} / \mathrm{g}$. While using $1 \mathrm{mg} / \mathrm{g}$ the immobilization is very rapid and almost total in a very short time, using $80 \mathrm{mg}$ of PFL/g of support, the immobilization yield is only $73.5 \%$ after $2 \mathrm{~h}$. This overloading was used in all further experiments to ensure full coating of the support with the enzyme and the successive layers.

This high enzyme loading increased the substrate diffusion limitations of p-nitrophenyl butyrate $(p \mathrm{NPB})$; thus, while using low enzyme loadings an increment of the enzyme activity is observed upon immobilization (around 10\%), at maximum loading, the enzyme activity even decreased, the immobilized enzyme has below $75 \%$ of the activity of the free enzyme. That may be visualized in Figure 2.

A

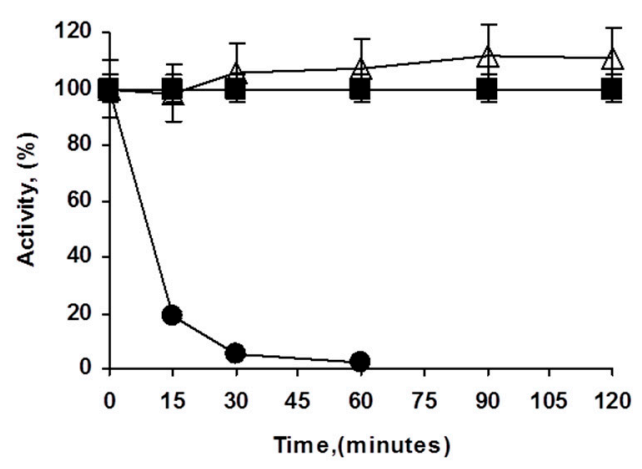

B

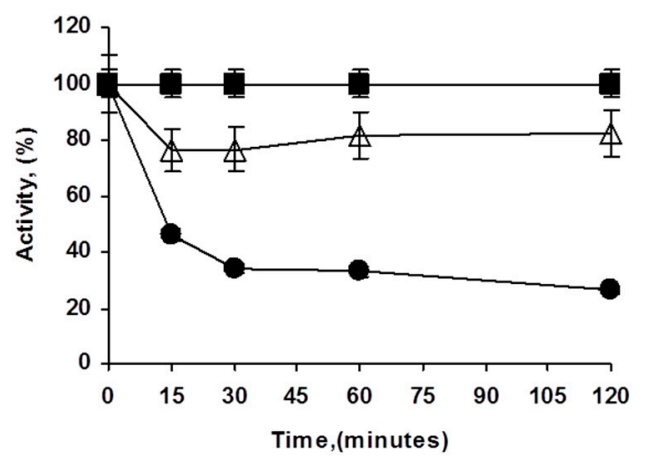

Figure 2. Immobilization courses of PFL on octyl agarose at different enzyme loadings ((A): $1 \mathrm{mg} / \mathrm{g}$, (B): $80 \mathrm{mg} / \mathrm{g})$. Experiments details as described in Methods. Circles: supernatant; triangles: suspension; squares: reference.

There are reports on the effect of enzyme loading and immobilization rate on the final immobilized enzyme stability [39,40]. To study if the use of overloaded PFL biocatalysts could have some effects on 
enzyme stability, both preparations were inactivated (Figure 3). The overloaded biocatalysts presented higher stability than the low loaded preparation, although part of this effect may be explained by an artifact caused by the diffusional limitations (the specific activity of the overloaded enzyme was $68 \%$ of that of the lowly loaded preparation), it looks that the stability of the overcrowded preparation was slightly higher under the inactivation conditions. That is, the use of overcrowded PFL preparations had even advantages in terms of enzyme stability.

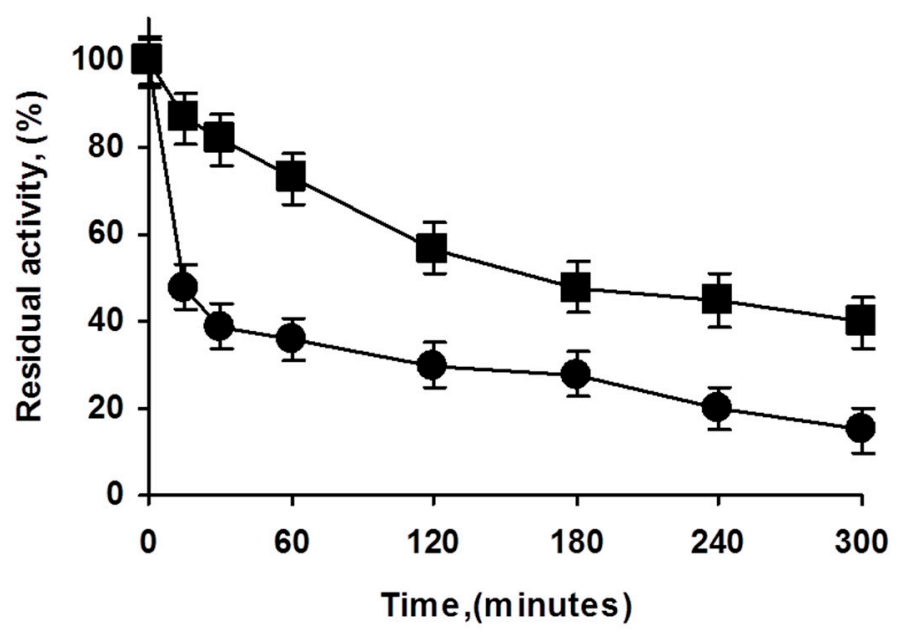

Figure 3. Effect of enzyme loading in the inactivation courses of octyl PFL biocatalysts. Inactivation carried out in $50 \mathrm{mM}$ Tris at $\mathrm{pH} 7$ and $75^{\circ} \mathrm{C}$. Experiments details as described in Methods. Squares: highly loaded biocatalyst; circles: lowly loaded biocatalyst.

\subsection{Coating of OA-PFL Biocatalysts with PEI}

The PEI coating of the immobilized PFL produced a clear increment in the enzyme activity versus $p$ NPB (around 10\%) (Table 1). This strategy has been used to stabilize other lipases immobilized on this support, and the positive effect on enzyme activity found here is an additional interesting feature [30-32]. This increase in activity is quite relevant considering that the overloaded biocatalyst already has diffusion limitations. A similar experiment using preparations with only $1 \mathrm{mg} / \mathrm{g}$ afforded an increment of enzyme activity of $30 \%$ (not shown).

Table 1. Mass activity of different PFL biocatalysts in hydrolysis of $1 \mathrm{mM} p$-nitrophenyl butyrate $(p \mathrm{NPB})$ at $25^{\circ} \mathrm{C}$ at $\mathrm{pH}$ 7. Experiments were performed as described in Methods. The loading of each layer as fairly similar, around $60-65 \mathrm{mg}$ of protein/g of octyl agarose.

\begin{tabular}{lc}
\hline \multicolumn{1}{c}{ PFL Preparations } & Activity versus $p$ NPB (U/g) \\
\hline OA-PFL & $96.1 \pm 1.0$ \\
OA-PFL-PEI & $105.8 \pm 1.2$ \\
OA-PFL-PEI-PFL & $132.2 \pm 1.1$ \\
OA-PFL-PEI-PFL-PEI & $123.4 \pm 1.0$ \\
OA-PFL-PEI-PFL-PEI-PFL & $107.7 \pm 0.9$ \\
\hline
\end{tabular}

Next, we analyzed the effect of the PEI coating in the stability of both, highly and lowly loaded biocatalysts. Figure 4 shows that the effect is not very relevant in contraposition with the results using other enzymes, where at least the overloaded enzyme biocatalysts increased its stability upon PEI coating [30,32]. This may be related to the very strong immobilization of the enzyme on octyl agarose [41], as the main reason for the PEI coating stabilization was associated to the prevention of the enzyme release [30,32]. 
A

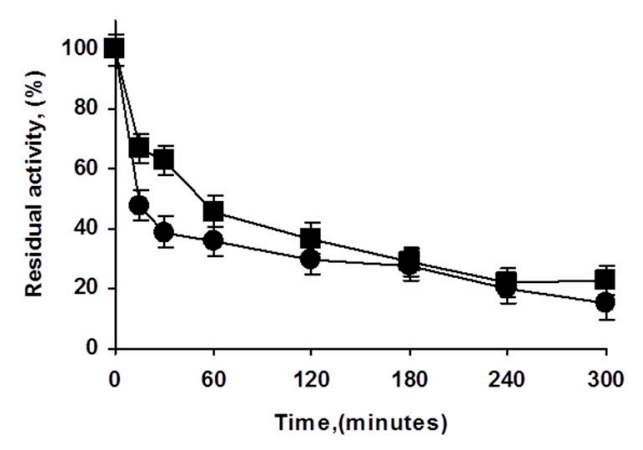

B

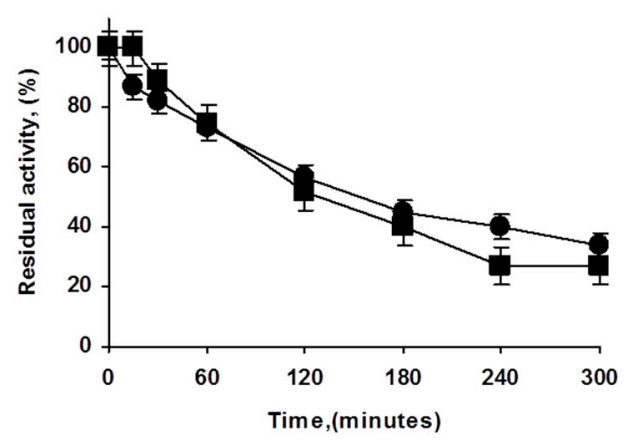

Figure 4. Effect of PEI coating of lowly (A) and highly (B) loaded PFL octyl biocatalysts. Inactivation carried out in $50 \mathrm{mM}$ Tris at $\mathrm{pH} 7$ and $75^{\circ} \mathrm{C}$. Other details are described in Methods section. Circles: unmodified preparations. Squares: PEI coated preparations.

\subsection{Immobilization of Further PFL Layers on OA-PFL-PEI Biocatalyst}

Immobilization of PFL on the OA-PFL-PEI biocatalyst is quite rapid (not shown results) and, in this instance, the final $p$ NPB activity of the biocatalyst increased less than $40 \%$ compared to the activity of the free and previously immobilized enzyme; this occurred even though the amount of immobilized enzyme was similar to that of the first PFL layer (around 80\%). This scarce effect of the immobilization of the second layer of enzyme on the biocatalyst activity may be caused by an increase of the diffusion limitations, mainly affecting the enzyme layer immobilized via interfacial activation on the octyl layer [38]. The coating of this second PFL layer with PEI decreased the $p$ NPB activity, which was only slightly higher than that of the first PFL-octyl layer. A further addition of PFL (again with around $80 \%$ immobilization yield) to get a three PFL layers biocatalyst decreased the $p$ NPB final activity of the biocatalyst (Table 1).

The explanation for this effect on $p$ NPB activity of the enzyme loading should be based on an increase of the substrate diffusion issue. PEI is a random coil polymer that permits the entry of the substrate without serious additional limitations. However, after the enzyme immobilization on the PEI layer, the substrate diffusion problems increased, as the protein layer really makes the entry of the substrate difficult. Moreover, the interactions of the rigid protein molecules with the PEI bed made that it lost mobility, promoting that the substrate diffusion become even more difficult. That way, the substrate can only circulate between the holes of the enzyme molecules in the upper layer increasing the tortuosity of the way the substrate must follow to reach the enzyme molecules located below [38]. This effect became very negative for the third layer of enzyme, when even the pore diameter of the support will be also reduced and the substrate diffusion limitations will be strongly increased. Now, the substrate will could not follow a straightforward way to reach the enzyme molecules in contact with the support, but should follow the tortuous route existing between enzyme molecules [38]. Figure 5 shows the sodium dodecyl sulfate -polyacrylamide gel electrophoresis study of the different biocatalysts, where the amount of protein proportionally increased with the number of enzyme layers. The band of more than $66 \mathrm{KD}$ could be the result of covalent dimers of PFL formed by Maillard reaction with the components of the commercial powder, as it is able to become immobilized on octyl agarose at low ionic strength.

From these results, it can be seen that just two enzyme layers produced the most positive effects on the biocatalyst mass activity, as the third layer produce even a decrease in the activity. Thus, we did not try to immobilize new layers of enzyme and focused to look for reactions where the three-layer biocatalyst offers a real advantage. In the next section, the activity of the different biocatalysts was analyzed using triacetin, a substrate that allowed higher concentrations than $p$ NPB. 


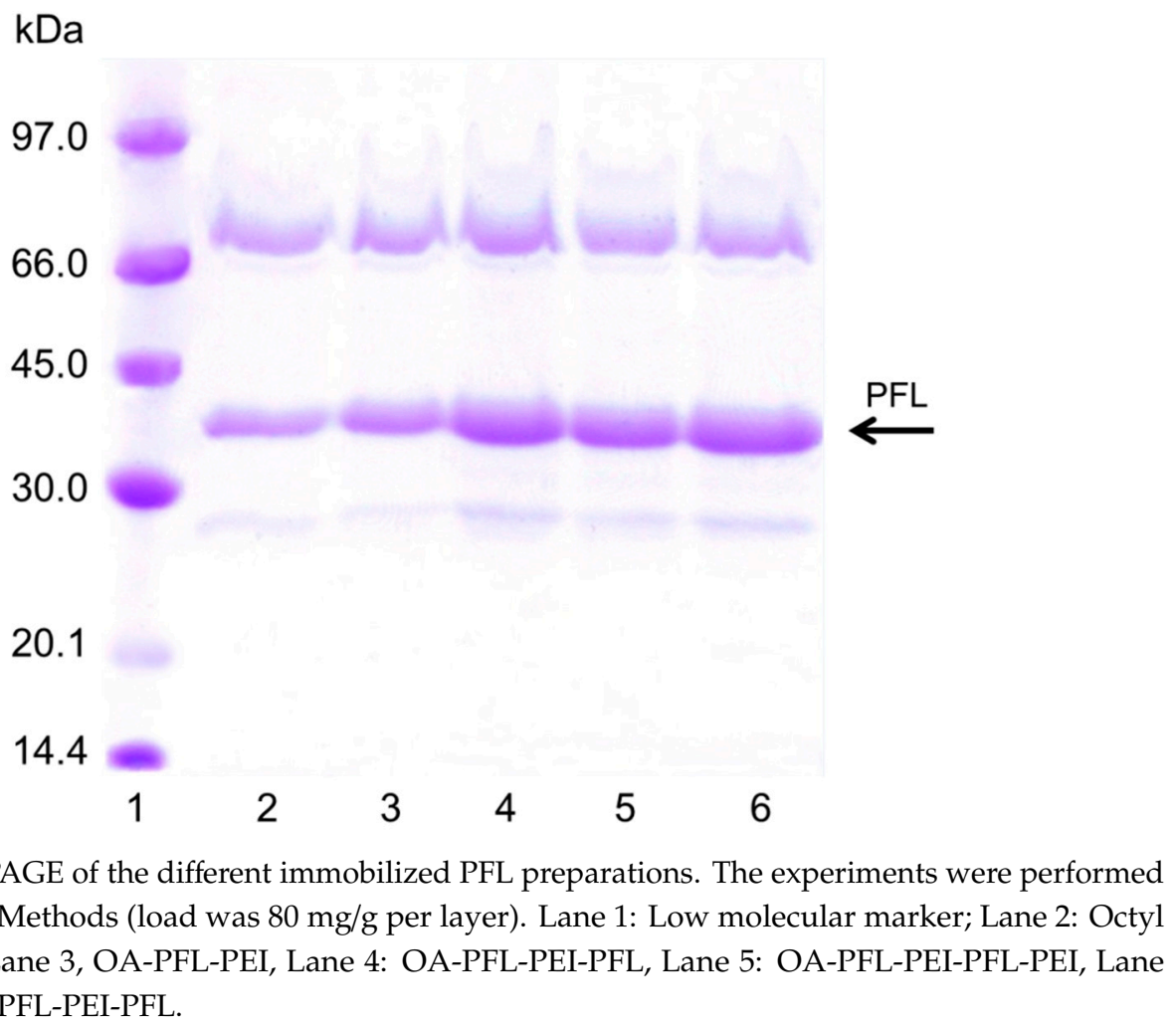

We checked the adsorption strength of PFL on the PEI bed, by incubating the biocatalysts in $1 \mathrm{M}$ ammonium sulfate at $\mathrm{pH} 7$, and we found that less than $1 \%$ of the enzyme molecules were released to the medium even at $37^{\circ} \mathrm{C}$. This showed the very strong immobilization of PFL on the PEI bed.

\subsection{Activity of the Different PFL Biocatalysts versus Triacetin}

Table 2 shows the activity of the different PFL preparations in triacetin hydrolysis at $25^{\circ} \mathrm{C}$. The activity of OA-PFL was decreased just by coating the enzyme with PEI. This decrease is very likely due to the high volumetric activity of the biocatalysts: there are substrate diffusion limitations even using $50 \mathrm{mM}$ of substrate. In fact, the activity considering the enzyme load and comparing the preparation of $1 \mathrm{mg}$ PFL/g of support, the activity of the overloaded preparation is around $70 \%$ of the expected one. As the PEI coating may reinforce these problems [38], an increase in the diffusion problems may be the responsible of this activity decrease instead of a direct negative effect of PEI on the enzyme properties versus this substrate. To investigate this, an immobilized OA-PFL preparation loaded with $1 \mathrm{mg}$ enzyme /g of support was modified with PEI: the activity increased by a $10 \%$ versus triacetin (not shown results), confirming that in the case of the overloaded preparation the decrease in activity is mainly caused by diffusion limitations and not by enzyme inactivation.

Table 2. Mass activity of different PFL biocatalysts in hydrolysis of $50 \mathrm{mM}$ triacetin at $\mathrm{pH}$. Activity is given in micromoles of acetic acid released per minute and gram of biocatalysts. T1: $25^{\circ} \mathrm{C}$. T2: $4{ }^{\circ} \mathrm{C}$ in the presence of $30 \%$ acetonitrile (v/v). Experiments were carried out as described in Methods.

\begin{tabular}{lcc}
\hline \multicolumn{1}{c}{ PFL Preparations } & $\begin{array}{c}\text { Activity versus Triacetin } \\
\text { (T1) (U/g) }\end{array}$ & $\begin{array}{c}\text { Activity versus Triacetin } \\
\text { (T2) (U/g) }\end{array}$ \\
\hline OA-PFL & $384.4 \pm 2.3$ & $17.6 \pm 0.3$ \\
OA-PFL-PEI & $277.0 \pm 1.8$ & $17.9 \pm 0.4$ \\
OA-PFL-PEI-PFL & $441.4 \pm 3.2$ & $33.6 \pm 1.1$ \\
OA-PFL-PEI-PFL-PEI & $793.6 \pm 4.4$ & $76.7 \pm 1.5$ \\
OA-PFL-PEI-PFL-PEI-PFL & $575.8 \pm 3.3$ & $82.0 \pm 1.4$ \\
\hline
\end{tabular}


Immobilization of a second layer of PFL increased the biocatalyst activity versus triacetin, and in this case, the coating of this second layer of PFL with PEI greatly increased the biocatalyst activity (almost doubling the total enzymatic activity). This difference with the effect of the first PEI coating may be based on the different immobilization strategy in the two enzyme layers: the first one was immobilized via interfacial activation, with the active center oriented towards the rigid support surface, while the second one was immobilized via ion exchange on a polymeric mobile and flexible bed. To check this, PFL was immobilized on a PEI coated support, and the treatment with PEI doubled the enzyme activity (not shown). A further last layer of PFL was again negative for the final volumetric activity of the biocatalysts, very likely because of a reinforcement of the diffusional limitations to the substrate [38], both from outside to inside in the pore of the support and from above to below through the three enzyme layers.

Trying to find conditions where the three layers of enzyme may have advantages, the temperature was decreased to $4{ }^{\circ} \mathrm{C}$ and $30 \%$ acetonitrile was added (this improved the selectivity of the reaction towards 1,2 diacetin [42]). These conditions decreased the biocatalyst activity from 384.4 to $17.6 \mathrm{U} / \mathrm{g}$ (Table 2), conditions where the substrate diffusion limitation may be greatly decreased (the relevant point is the substrate diffusion versus substrate conversion rates). The effect of the PEI modification of OA-PFL on the enzyme activity was even slightly positive (though at $25^{\circ} \mathrm{C}$ the biocatalyst activity decreased). The second layer of PFL increased the activity by almost a twofold factor, and the same may be said of the modification with PEI. Under these reaction conditions, addition of the third layer of PFL produced a small increase of biocatalyst activity (from 76.7 to $82 \mathrm{U} / \mathrm{g}$ ), lower that the values expected from the second PFL layer (which, considering the amount of immobilized protein, should be triple of the activity of the one PFL layer), but enough to increase the total volumetric activity of the biocatalyst. That is, when the enzyme specific activity was decreased and that way the substrate diffusional limitations were diminished, the positive effect of the multilayers on the biocatalyst activity increased. The limit of the interest of increasing the number of layers will depend on many factors: substrate, substrate concentration and experimental conditions.

\subsection{Treatment of the Biocatalysts with Glutaraldehyde}

Some authors propose the treatment with glutaraldehyde of enzymes immobilized via ion exchange to prevent the enzyme release if high ionic strength or drastic $\mathrm{pH}$ values are used (e.g., hydrolysis of concentrated oils solutions, where the $\mathrm{pH}$ may decrease below 4 in the presence of high concentrations of free fatty acids) [23,43-45].

Thus, in a last trial, the biocatalysts were treated with glutaraldehyde (Table 3). When the second layer was treated with glutaraldehyde, only 14 and $8 \%$ of the activity was lost using triacetin at $25{ }^{\circ} \mathrm{C}$ and at $4{ }^{\circ} \mathrm{C}$ in $30 \%$ acetonitrile, respectively. This shows that the treatment with glutaraldehyde of the second PFL layer do not harm significantly the PFL structure. However, the effect of PEI coating of the biocatalyst treated with glutaraldehyde was more negative: the biocatalyst lost more than 25 and almost $50 \%$ of its activity in triacetin hydrolysis at $25{ }^{\circ} \mathrm{C}$ or at $4{ }^{\circ} \mathrm{C} / 30 \%$ acetonitrile, respectively. In the third PFL layer, the effect of glutaraldehyde treatment of the previous layers was also negative and the biggest drop in activity was observed in triacetin hydrolysis at $25^{\circ} \mathrm{C}$, where the biocatalyst lost about $28 \%$ of its activity. These negative effects of glutaraldehyde treatment in enzyme activity may be based on the PEI crosslinking that may increase the diffusion problems as the polymer will not be longer random coil [38].

An SDS-PAGE study showed that only the last PFL layer, not treated with glutaraldehyde, can be released from the biocatalyst, confirming the successful massive intermolecular crosslinking of the other two underlying enzyme layers (Figure 6). This treatment clearly prevents enzyme release from the support even under very harsh conditions (boiling in the presence of SDS). 
Table 3. Effect of the glutaraldehyde treatment of the PFL biocatalysts on enzyme activity in the hydrolysis of $50 \mathrm{mM}$ triacetin at pH 5. T1: $25^{\circ} \mathrm{C}$. T2: $4{ }^{\circ} \mathrm{C}$ in the presence of $30 \%$ acetonitrile (v/v). The data are given as relative activity, considering the activity of the respective no treated preparation as $100 \%$. Experiments were performed as described in Methods.

\begin{tabular}{lcc}
\hline \multicolumn{1}{c}{ PFL Preparations } & $\begin{array}{c}\text { Relative Activity versus } \\
\text { Triacetin, (\%) (T1) }\end{array}$ & $\begin{array}{c}\text { Relative Activity versus } \\
\text { Triacetin, (\%) (T2) }\end{array}$ \\
\hline OA -PFL-PEI-PFL-GA 1\% & $86.4 \pm 1.9$ & $91.9 \pm 3.2$ \\
\hline OA -PFL-PEI-PFL-GA 1\%-PEI & $73.6 \pm 3.1$ & $51.2 \pm 2.1$ \\
\hline OA -PFL-PEI-PFL-GA 1\%-PEI-PFL & $72.5 \pm 1.1$ & $90.4 \pm 3.1$ \\
\hline
\end{tabular}

$\mathrm{kDa}$

97.0

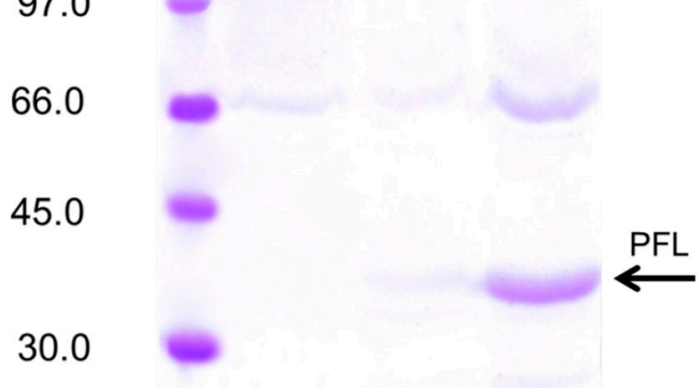

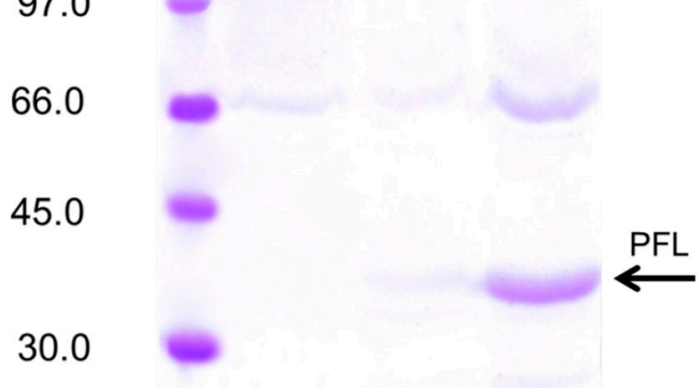

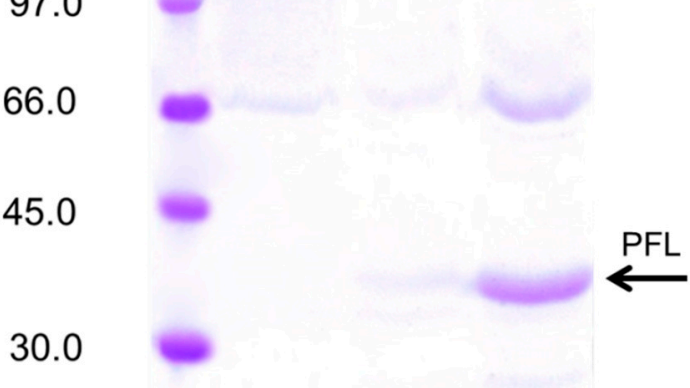

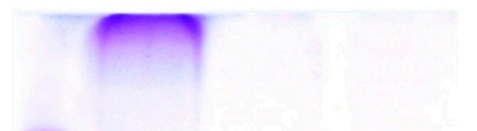

20.1

14.4

$$
12 \quad 3 \quad 4
$$

Figure 6. SDS-PAGE of the glutaraldehyde modified PFL preparations. The experiments were performed as described in Methods (load was $80 \mathrm{mg} / \mathrm{g}$ per layer). Lane 1: Low molecular marker; Lane 2: OA-PFL-PEI-PFL-Glutaraldehyde, Lane 3: OA-PFL-PEI-PFL-Glutaraldehyde-PEI, Lane 4: OA-PFL-PEI-PFL-Glutaraldehyde-PEI-PFL.

Figure 7 shows how the treatment of the OA-PFL-PEI with glutaraldehyde has a relevant stabilizing effect. Although the first inactivation steps are fairly similar, there was a fraction (accounting for $75 \%$ of the enzyme activity) that is much more stable than the unmodified biocatalysts. The stabilization can be produced by either intermolecular or intramolecular crosslinking. To check the importance of the intramolecular crosslinking, the lowly loaded preparation coated with PEI was modified with glutaraldehyde, and the resulting stabilization effect was negligible. That suggests that the main effect of the glutaraldehyde treatment in the overloaded preparations was caused by intermolecular crosslinking. In any case, the positive effect of the glutaraldehyde treatment was very clear in terms of stability, although it was not as positive in terms of activity. The final decision will depend on the necessity or not to improve enzyme stability and prevent enzyme release. 
A

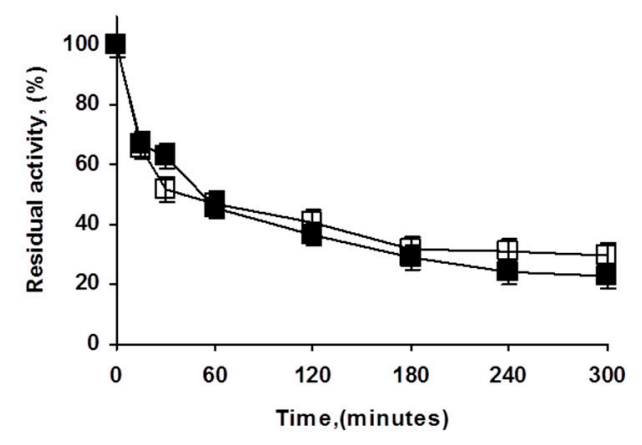

B

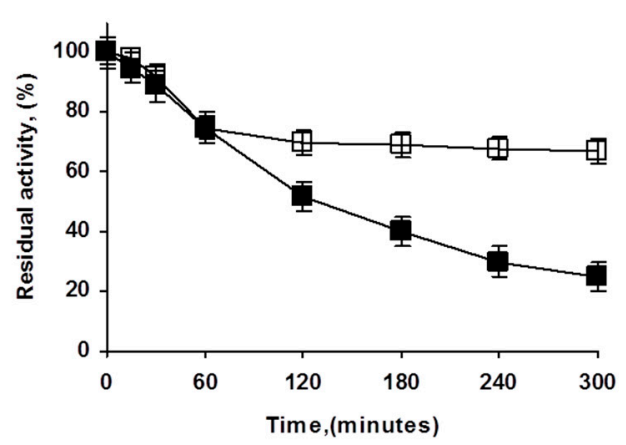

Figure 7. Effect of glutaraldehyde modification of OA-PFL-PEI biocatalysts preparations at different enzyme loadings ((A): lowly loaded, (B): highly loaded). Inactivation was carried out in $50 \mathrm{mM}$ Tris at $\mathrm{pH} 7$ and $75{ }^{\circ} \mathrm{C}$ as described in Methods. Solid symbols: PEI coated octyl-PFL; Hollow symbols: Glutaraldehyde modified biocatalysts.

\section{Materials and Methods}

\subsection{Materials}

Lipase from Pseudomonas fluorescens (PFL, $0.132 \mathrm{mg}$ protein/mg powder, determined by Bradford method [46]), polyethylenimine (PEI) (MW 25,000), triacetin, p-nitrophenyl butyrate (p-NPB), glutaraldehyde solution Grade II $\left(25 \%\right.$ in $\left.\mathrm{H}_{2} \mathrm{O}\right)$ and acetonitrile for HPLC (gradient grade, $\geq 99.9 \%$ ) were purchased from Sigma Aldrich. Cl-4B octyl-Sepharose beads and low molecular weight (LMW) marker for SDS electrophoresis (14.4-97 kDa) were purchased from GE Healthcare. All other reagents were of analytical grade.

\subsection{Methods}

All experiments were performed by triplicate and the values are given as mean values and experimental errors.

\subsubsection{Immobilization of PFL}

\section{Immobilization of PFL on Octyl Agarose (OA)}

PFL was immobilized on octyl-agarose using $1 \mathrm{mg} / \mathrm{g}$ and $80 \mathrm{mg} / \mathrm{g}$ (overload of the support capacity that is around $60 \mathrm{mg} / \mathrm{g}$ ). A proper mass of lipase was diluted in $5 \mathrm{mM}$ sodium phosphate buffer ( $\mathrm{pH} 7$ ) and then added to the support in a ratio $1 / 10$ or $1 / 15$, for $1 \mathrm{mg} / \mathrm{g}$ and $80 \mathrm{mg} / \mathrm{g}$, respectively. The immobilization was performed under mechanical stirring at room temperature during 2 hours. A reference suspension was utilized to check the effects of the immobilization conditions on the PFL activity; this was the enzyme under identical conditions and mixed with inert agarose beads. Samples of supernatant and suspension were periodically withdrawn and their activities were measured using the $p$ NPB assay described below.

Coating of the Immobilized Enzyme with PEI

The immobilized PFL preparations were treated with $10 \% \mathrm{w} / \mathrm{v}$ PEI solution at $\mathrm{pH} 7$ [47]. This step was conducted under gentle stirring at $4{ }^{\circ} \mathrm{C}$ during 18 hours. Subsequently, the coated biocatalyst was filtered and washed many times with distilled water.

Immobilization of PFL on PEI-coated Biocatalysts

PFL was immobilized on the overloaded biocatalyst and PEI coated offering $80 \mathrm{mg} / \mathrm{g}$ in $5 \mathrm{mM}$ sodium phosphate at $\mathrm{pH} 7$ during 2 hours at $25^{\circ} \mathrm{C}$. Then, the biocatalyst was filtered and washed with 
an excess of distilled water. In some cases, the biocatalyst was treated with glutaraldehyde solution $1 \%$ $(\mathrm{v} / \mathrm{v})$ in $50 \mathrm{mM}$ sodium phosphate at $\mathrm{pH} 7$, for 1 hour [48-50].

\subsubsection{Determination of Enzymatic Activities}

Hydrolysis of p-nitrophenyl Butyrate (p-NPB)

In the hydrolysis of $\mathrm{p}-\mathrm{NPB}, 50 \mu \mathrm{L}$ of substrate $(50 \mathrm{mM})$ was added to $2.5 \mathrm{~mL}$ of $25 \mathrm{mM}$ sodium phosphate buffer at $\mathrm{pH} 7$ and $25^{\circ} \mathrm{C}$. The reaction was started by adding $50-100 \mu \mathrm{L}$ of the enzyme sample (solution or suspension) and the hydrolysis continued during 90 seconds, with the continuous liberation of the product, the p-nitrophenol, which was detected at $348 \mathrm{~nm}$ using a spectrophotometer with magnetic stirring and thermostatization system.

Hydrolysis of Triacetin

Hydrolysis of triacetin was performed using $50 \mathrm{mM}$ of substrate at $\mathrm{pH} 5$ to prevent acyl migration [42]. $0.1 \mathrm{~g}$ of wet biocatalyst was added to the substrate solution at $25^{\circ} \mathrm{C}$ or, in some instances, at $4{ }^{\circ} \mathrm{C}$ in presence of $30 \%$ acetonitrile to reduce the enzyme activity [42]. The catalytic activity of the biocatalysts was determined by the production of 1,2 diacetin, at conversions degrees between 15-22\%. This conversion was measured using a HPLC (Kromasil C18 column of $15 \mathrm{~cm} \times$ $0.46 \mathrm{~cm}$ ) with a flow rate of $1 \mathrm{~mL} / \mathrm{min}$ of $15 \%$ acetonitrile- $85 \%$ water as mobile phase. The compounds were detected with a UV detector (Waters 486 ) at $230 \mathrm{~nm}$ and the retention times were about $4 \mathrm{~min}$ for 1,2 diacetin and $18 \mathrm{~min}$ for triacetin [47].

\subsubsection{Electrophoresis SDS-PAGE}

The SDS-PAGE analyses were carried out using $12 \%$ and $5 \%$ of polyacrylamide as resolution gel and concentration gel, respectively [51]. The immobilized PFL samples were diluted in a solution $10 \%(\mathrm{v} / \mathrm{v})$ SDS, calculating a final protein concentration of $15 \mathrm{mg}$ of protein per $\mathrm{ml}$ in the solution. The samples were boiled for 5 minutes, centrifuged, boiled again ( 5 minutes) and, finally, $15 \mu \mathrm{L}$ of the samples were loaded in electrophoresis gel. $5 \mu \mathrm{L}$ of Low Molecular Weight marker proteins (LMW-SDS Marker-14.4-97 kDa) were used as standard. The gels were stained with Coomassie brilliant blue.

\subsubsection{Thermal Inactivation}

Enzyme biocatalysts (solution for free enzyme or suspension for immobilized enzyme) were incubated in $50 \mathrm{mM}$ Tris at $\mathrm{pH} 7$ and incubated at the indicated temperature (immobilized enzyme was diluted 1:9, free enzyme was at $1 \mathrm{mg} / \mathrm{ml}$ ). A temperature that gave a reasonable inactivation rate was selected. Periodically, samples were taken and their activity versus $p$ NPB was quantified considering $100 \%$ the activity of the initial preparation.

\section{Conclusions}

A biocatalyst with three layers of PFL has been built. This was based on the use of PEI as glue. Modification of the enzyme with PEI using lowly loaded enzyme preparations is positive for $p$ NPB and triacetin hydrolysis, but using the highly loaded biocatalyst it is only clear when triacetin is hydrolyzed at $4{ }^{\circ} \mathrm{C}$ and in the presence of solvents but not at $25^{\circ} \mathrm{C}$, very likely due to the increase in the substrate diffusion limitations. The third layer of enzyme only increases the biocatalyst activity under conditions where the specific activity of the enzyme is not very high. That is, the number of multilayers that can be built with increase in the final biocatalyst activity depends on the activity that the biocatalyst expresses versus the specific substrate and under the specific conditions. This strategy could be extrapolated to other lipases, and also to other industrially important enzymes. For other enzymes, the initial immobilization strategy should be changed by other immobilization method (e.g., covalent), useful for most enzymes. These studies are in course in our laboratory. 
Author Contributions: N.S.R., S.A.-P. and C.M.-S.: investigation, formal analysis, writing-original draft preparation, Y.L.: investigation, V.C.-C.: methodology, formal analysis, writing-review and editing L.R.B.G.: methodology, funding acquisition, writing - review and editing R.F.-L.: funding acquisition, supervision, formal analysis, methodology, conceptualization, writing-original draft preparation, review and editing.

Funding: This research was funded by MICIU grant number CTQ2017-86170-R (Spain). N. S. R. thanks to CNPq for a predoctoral fellowship (CNPq scholarship-Brazil).

Acknowledgments: Martinez (Novozymes Spain) is gratefully recognized by the donation of the enzymes.

Conflicts of Interest: The authors declare no conflict of interest.

\section{References}

1. Garcia-Galan, C.; Berenguer-Murcia, Á.; Fernandez-Lafuente, R.; Rodrigues, R.C. Potential of different enzyme immobilization strategies to improve enzyme performance. Adv. Synth. Catal. 2011, 353, 2885-2904. [CrossRef]

2. Bilal, M.; Iqbal, H.M.N. Sustainable bioconversion of food waste into high-value products by immobilized enzymes to meet bio-economy challenges and opportunities-A review. Food Res. Int. 2019, 123, $226-240$. [CrossRef]

3. Barbosa, O.; Ortiz, C.; Berenguer-Murcia, Á.; Torres, R.; Rodrigues, R.C.; Fernandez-Lafuente, R. Strategies for the one-step immobilization-purification of enzymes as industrial biocatalysts. Biotechnol. Adv. 2015, 33, 435-456. [CrossRef] [PubMed]

4. Hwang, E.T.; Lee, S. Multienzymatic Cascade Reactions via Enzyme Complex by Immobilization. ACS Catal. 2019, 9, 4402-4425. [CrossRef]

5. Rodrigues, R.C.; Ortiz, C.; Berenguer-Murcia, Á.; Torres, R.; Fernández-Lafuente, R. Modifying enzyme activity and selectivity by immobilization. Chem. Soc. Rev. 2013, 42, 6290-6307. [CrossRef] [PubMed]

6. Sheldon, R.A.; Van Pelt, S. Enzyme immobilisation in biocatalysis: Why, what and how. Chem. Soc. Rev. 2013, 42, 6223-6235. [CrossRef]

7. Di Cosimo, R.; Mc Auliffe, J.; Poulose, A.J.; Bohlmann, G. Industrial use of immobilized enzymes. Chem. Soc. Rev. 2013, 42, 6437-6474. [CrossRef]

8. Brady, D.; Jordaan, J. Advances in enzyme immobilisation. Biotechnol. Lett. 2009, 31, 1639-1650. [CrossRef]

9. Sheldon, R.A. Enzyme Immobilization: The Quest for Optimum Performance. Adv. Synth. Catal. 2007, 349, 1289-1307. [CrossRef]

10. Bilal, M.; Zhao, Y.; Noreen, S.; Zakir, S.; Shah, H.; Bharagava, N.; Iqbal, H.M.N. Modifying bio-catalytic properties of enzymes for efficient biocatalysis: A review from immobilization strategies viewpoint. Biocatal. Biotransf. 2019, 37, 159-182. [CrossRef]

11. Mateo, C.; Palomo, J.M.; Fernandez-Lorente, G.; Guisan, J.M.; Fernandez-Lafuente, R. Improvement of enzyme activity, stability and selectivity via immobilization techniques. Enzyme Microb. Technol. 2007, 40, 1451-1463. [CrossRef]

12. Santos, J.C.S.D.; Barbosa, O.; Ortiz, C.; Berenguer-Murcia, A.; Rodrigues, R.C.; Fernandez-Lafuente, R. Importance of the Support Properties for Immobilization or Purification of Enzymes. ChemCatChem 2015, 7 , 2413-2432. [CrossRef]

13. Ansari, S.A.; Husain, Q. Potential applications of enzymes immobilized on/in nano materials: A review. Biotechnol. Adv. 2012, 30, 512-523. [CrossRef] [PubMed]

14. Verma, M.L.; Barrow, C.J.; Puri, M. Nanobiotechnology as a novel paradigm for enzyme immobilisation and stabilisation with potential applications in biodiesel production. Appl. Microbiol. Biotechnol. 2013, 97, $23-39$. [CrossRef] [PubMed]

15. Vaghari, H.; Jafarizadeh-Malmiri, H.; Mohammadlou, M.; Berenjian, A.; Anarjan, N.; Jafari, N.; Nasiri, S. Application of magnetic nanoparticles in smart enzyme immobilization. Biotechnol. Lett. 2015, 223-233. [CrossRef] [PubMed]

16. Min, K.; Yoo, Y.J. Recent Progress in Nanobiocatalysis for Enzyme Immobilization and Its Application. Biotechnol. Bioprocess Eng. 2014, 19, 553-567. [CrossRef]

17. Bar-Even, A.; Milo, R.; Noor, E.; Tawfik, D.S. The Moderately Efficient Enzyme: Futile Encounters and Enzyme Floppiness. Biochemistry 2015, 54, 4969-4977. [CrossRef] [PubMed] 
18. Virgen-Ortíz, J.J.; Dos Santos, J.C.S.; Berenguer-Murcia, Á.; Barbosa, O.; Rodrigues, R.C.; Fernandez-Lafuente, R. Polyethylenimine: A very useful ionic polymer in the design of immobilized enzyme biocatalysts. J. Mater. Chem. B 2017, 5, 7461-7490. [CrossRef]

19. Onda, M.; Ariga, K.; Kunitake, T. Activity and stability of glucose oxidase in molecular films assembled alternately with polyions. J. Biosci. Bioeng. 1999, 87, 69-75. [CrossRef]

20. Rodríguez, M.C.; Rivas, G.A. Assembly of glucose oxidase and different polyelectrolytes by means of electrostatic layer-by-layer adsorption on thiolated gold surface. Electroanalysis 2004, 16, 1717-1722. [CrossRef]

21. Forrest, S.R.; Elmore, B.B.; Palmer, J.D. Activity and lifetime of organophosphorous hydrolase (OPH) immobilized using layer-by-layer nano self-assembly on silicon microchannels. Catal. Today 2007, 120, 30-34. [CrossRef]

22. Peirce, S.; Virgen-Ortíz, J.J.; Tacias-Pascacio, V.G.; Rueda, N.; Bartolome-Cabrero, R.; Fernandez-Lopez, L.; Russo, M.E.; Marzocchella, A.; Fernandez-Lafuente, R. Development of simple protocols to solve the problems of enzyme coimmobilization. Application to coimmobilize a lipase and a $\beta$-galactosidase. RSC Adv. 2016, 6, 61707-61715. [CrossRef]

23. Zaak, H.; Kornecki, J.F.; Siar, E.-H.; Fernandez-Lopez, L.; Corberán, V.C.; Sassi, M.; Fernandez-Lafuente, R. Coimmobilization of enzymes in bilayers using pei as a glue to reuse the most stable enzyme: Preventing pei release during inactivated enzyme desorption. Process Biochem. 2017, 61, 95-101. [CrossRef]

24. Velasco-Lozano, S.; Benítez-Mateos, A.I.; López-Gallego, F. Co-immobilized Phosphorylated Cofactors and Enzymes as Self-Sufficient Heterogeneous Biocatalysts for Chemical Processes. Angew. Chemie - Int. Ed. 2017, 56, 771-775. [CrossRef] [PubMed]

25. Benítez-Mateos, A.I.; San Sebastian, E.; Ríos-Lombardía, N.; Morís, F.; González-Sabín, J.; López-Gallego, F. Asymmetric Reduction of Prochiral Ketones by Using Self-Sufficient Heterogeneous Biocatalysts Based on NADPH-Dependent Ketoreductases. Chem.-A Eur. J. 2017, 23, 16843-16852. [CrossRef] [PubMed]

26. López-Gallego, F.; Jackson, E.; Betancor, L. Heterogeneous Systems Biocatalysis: The Path to the Fabrication of Self-Sufficient Artificial Metabolic Cells. Chem. - A Eur. J. 2017, 23, 17841-17849. [CrossRef] [PubMed]

27. Xie, Z.F. Pseudomonas fluorescens lipase in asymmetric synthesis. Tetrahedron: Asymmetry 1991, 2, 733-750. [CrossRef]

28. Sánchez, D.A.; Tonetto, G.M.; Ferreira, M.L. Burkholderia cepacia lipase: A versatile catalyst in synthesis reactions. Biotechnol. Bioeng. 2018, 115, 6-24. [CrossRef]

29. Rios, N.S.; Pinheiro, B.B.; Pinheiro, M.P.; Bezerra, R.M.; dos Santos, J.C.S.; Gonçalves, L.R.B. Biotechnological potential of lipases from Pseudomonas: Sources, properties and applications. Process Biochem. 2018, 75, 99-120. [CrossRef]

30. Fernandez-Lopez, L.; Virgen-OrtÍz, J.J.; Pedrero, S.G.; Lopez-Carrobles, N.; Gorines, B.C.; Otero, C.; Fernandez-Lafuente, R. Optimization of the coating of octyl-CALB with ionic polymers to improve stability and decrease enzyme leakage. Biocatal. Biotransformation 2017, 36, 47-56. [CrossRef]

31. Zaak, H.; Fernandez-Lopez, L.; Otero, C.; Sassi, M.; Fernandez-Lafuente, R. Improved stability of immobilized lipases via modification with polyethylenimine and glutaraldehyde. Enzyme Microb. Technol. 2017, 106, 67-74. [CrossRef] [PubMed]

32. Fernandez-Lopez, L.; Pedrero, S.G.; Lopez-Carrobles, N.; Virgen-Ortíz, J.J.; Gorines, B.C.; Otero, C.; Fernandez-Lafuente, R. Physical crosslinking of lipase from Rhizomucor miehei immobilized on octyl agarose via coating with ionic polymers: Avoiding enzyme release from the support. Process Biochem. 2017, 54, 81-88. [CrossRef]

33. Manoel, E.A.; Dos Santos, J.C.S.; Freire, D.M.G.; Rueda, N.; Fernandez-Lafuente, R. Immobilization of lipases on hydrophobic supports involves the open form of the enzyme. Enzyme Microb. Technol. 2015, 71, 53-57. [CrossRef] [PubMed]

34. Rodrigues, R.C.; Virgen-Ortíz, J.J.; dos Santos, J.C.S.; Berenguer-Murcia, Á.; Alcantara, A.R.; Barbosa, O.; Ortiz, C.; Fernandez-Lafuente, R. Immobilization of lipases on hydrophobic supports: Immobilization mechanism, advantages, problems, and solutions. Biotechnol. Adv. 2019. In Press. [CrossRef] [PubMed]

35. Hamilton, B.K.; Gardner, C.R.; Colton, C.K. Effect of Diffusional Limitations on Lineweawer-Burk Plots for Immobilized Enzymes. AIChE J. 1974, 20, 503-510. [CrossRef]

36. Muller, J.; Zwing, T. An experimental verification of the theory of diffusion limitation of immobilized enzymes. Biochim. Biophys. Acta 1982, 705, 117-123. [CrossRef] 
37. Berendsen, W.R.; Lapin, A.; Reuss, M. Investigations of Reaction Kinetics for Immobilized Enzymes Identification of Parameters in the Presence of Diffusion Limitation. Biotechnol. Prog. 2006, 22, 1305-1312. [CrossRef]

38. Shen, L.; Chen, Z. Critical review of the impact of tortuosity on diffusion. Chem. Eng. Sci. 2007, 62, 3748-3755. [CrossRef]

39. Fernandez-Lopez, L.; Pedrero, S.G.; Lopez-Carrobles, N.; Gorines, B.C.; Virgen-Ortíz, J.J.; FernandezLafuente, R. Effect of protein load on stability of immobilized enzymes. Enzyme Microb. Technol. 2017, 98, 18-25. [CrossRef]

40. Zaak, H.; Siar, E.-H.; Kornecki, J.F.; Fernandez-Lopez, L.; Pedrero, S.G.; Virgen-Ortíz, J.J.; Fernandez-Lafuente, R. Effect of immobilization rate and enzyme crowding on enzyme stability under different conditions. The case of lipase from Thermomyces lanuginosus immobilized on octyl agarose beads. Process Biochem. 2017, 56, 117-123. [CrossRef]

41. Rios, N.S.; Mendez-sanchez, C.; Arana-Peña, S.; Rueda, N.; Ortiz, C.; Gonçalves, L.R.B.; Fernandez-Lafuente, R. Immobilization of lipase from Pseudomonas fluorescens on glyoxyl-octyl-agarose beads: Improved stability and reusability. Biochim. Biophys. Acta Proteins Proteom. 2019. In Press. [CrossRef] [PubMed]

42. Hernandez, K.; Garcia-Verdugo, E.; Porcar, R.; Fernandez-Lafuente, R. Hydrolysis of triacetin catalyzed by immobilized lipases: Effect of the immobilization protocol and experimental conditions on diacetin yield. Enzyme Microb. Technol. 2011, 48, 510-517. [CrossRef] [PubMed]

43. Sun, J.; Wang, C.; Wang, Y.; Ji, S.; Liu, W. Immobilization of carbonic anhydrase on polyethylenimine/dopamine codeposited membranes. J. Appl. Polym. Sci. 2019, 136, 47784. [CrossRef]

44. Zeuner, B.; Ma, N.; Berendt, K.; Meyer, A.S.; Andric, P.; Jørgensen, J.H.; Pinelo, M. Immobilization of alcohol dehydrogenase on ceramic silicon carbide membranes for enzymatic $\mathrm{CH}_{3} \mathrm{OH}$ production. J. Chem. Technol. Biotechnol. 2018, 93, 2952-2961. [CrossRef]

45. Shi, X.; Zhao, L.; Pei, J.; Ge, L.; Wan, P.; Wang, Z.; Xiao, W. Highly enhancing the characteristics of immobilized thermostable $\beta$-glucosidase by $\mathrm{Zn}^{2+}$. Process Biochem. 2018, 66, 89-96. [CrossRef]

46. Bradford, M.M. A rapid and sensitive method for the quantitation of microgram quantities of protein utilizing the principle of protein-dye binding. Anal. Biochem. 1976, 72, 248-254. [CrossRef]

47. Arana-Peña, S.; Lokha, Y.; Fernández-Lafuente, R. Immobilization on octyl-agarose beads and some catalytic features of commercial preparations of lipase A from Candida antarctica (Novocor ADL): Comparison with immobilized lipase B from Candida antarctica. Biotechnol. Prog. 2019, 35, e2735. [CrossRef]

48. Migneault, I.; Dartiguenave, C.; Bertrand, M.J.; Waldron, K.C. Glutaraldehyde: Behavior in aqueous solution, reaction with proteins, and application to enzyme crosslinking. Biotechniques 2004, 37, 790-802. [CrossRef]

49. Barbosa, O.; Ortiz, C.; Berenguer-Murcia, Á.; Torres, R.; Rodrigues, R.C.; Fernandez-Lafuente, R. Glutaraldehyde in bio-catalysts design: A useful crosslinker and a versatile tool in enzyme immobilization. RSC Adv. 2014, 4, 1583-1600. [CrossRef]

50. Wine, Y.; Cohen-Hadar, N.; Freeman, A.; Frolow, F. Elucidation of the mechanism and end products of glutaraldehyde crosslinking reaction by X-ray structure analysis. Biotechnol. Bioeng. 2007, 98, 711-718. [CrossRef]

51. Laemmli, U.K. Cleavage of structural proteins during the assembly of the head of bacteriophage T4. Nature 1970, 227, 680-685. [CrossRef] [PubMed]

(C) 2019 by the authors. Licensee MDPI, Basel, Switzerland. This article is an open access article distributed under the terms and conditions of the Creative Commons Attribution (CC BY) license (http://creativecommons.org/licenses/by/4.0/). 